\title{
Adab kepada Guru dan Orang Tua: Studi Pemahaman Siswa pada Materi Akhlak
}

\author{
Leni Elpita Sari, ${ }^{1}$ Abdul Rahman, ${ }^{2}$ Baryanto, ${ }^{3}$ \\ 1,2,3 Fakutas Tarbiyah Institut Agama Islam Negeri (IAIN) Curup, Bengkulu \\ ${ }^{1}$ lenielpitacrp@gmail.com, ${ }^{2}$ abdulrahman@iaincurup.ac.id, 3baryanto2014@yahoo.co.id.
}

\begin{abstract}
A good moral character is a keyword for the success of educational processes. Everyone will never be able to control themselves if only relying on the knowledge they have without being espoused by a noble moral character. Hence, each teacher who establishes interactions with students is given a big responsibility to guide his/her students' moral character. Seeing that responsibility, the current study aimed at finding out the depiction of the teacher's efforts to give understanding to students in a public school, MTS No. 2 Kepahiang, as regards good manners to parents and teachers, using a qualitative approach with the primary informant, namely the Akidah Akhlak teacher in that school. This study concluded that the teacher handling Akidah Akhlak lesson had made good efforts and been adequately helpful in giving understanding to students about good manners to parents and teachers. This entity was seen from students' behavior in doing their activities both at school and afterschool although based on the evaluation results, it was not a hundred percent of students who had been able to apply their understanding of the importance of good manners to parents and teachers.

Akhlak yang baik adalah kata kunci keberhasilan proses pendidikan. Setiap orang tidak akan mampu mengendalikan dirinya jika hanya bersandar pada pengetahuan yang dimilikinya kecuali dibarengi dengan akhlak mulia. Dengan demikian setiap guru yang melakukan interaksi dengan murid diberikan tanggungjawab yang besar untuk membina akhlak anak didiknya. Melihat besarnya tanggungjawab itu penelitian ini bertujuan untuk menemukan gambaran tentang upaya guru dalam memberikan pemahaman kepada siswa di MTs. Negeri 02 Kepahiang tentang adab baik kepada orang tua maupun guru, melalui pendekatan kualitatif dengan informan utama yaitu guru Akidah Akhlak di sekolah tersebut. Peneltian ini memperoleh simpulan bahwa guru pelajaran akidah akhlak sudah berusaha dan cukup membantu dalam memberikan pemahaman kepada siswa dalam hal adab kepada orang tua dan guru, hal ini terlihat dari perilaku peserta didik dalam menjalani aktivitas di sekolah maupun di luar sekolah meskipun dari hasil evaluasi belum sepenuhnya siswa mampu menerapkan pemahaman mereka tentang pentingnya adab baik kepada orang tua maupun guru.
\end{abstract}

Keywords: Manner, Moral Character, Parents, Teachers. 
| LENI ELPITA SARI, DKK. | Adab kepada Guru dan Orang Tua...

\section{A. Pendahuluan}

Landasan dasar pendidikan Islam adalah al-Qur'an dan Hadis, tujuannya agar manusia tunduk dan patuh kepada ajaran agama dan memiliki akhlak yang mulia. Karena hal itulah satu-satunya jalan untuk memperoleh kemuliaan dalam pandangan Allah. ${ }^{1}$ Tentu untuk memperolehnya tidak lain adalah ilmu pengetahuan tersebut. ${ }^{2}$ Dengan demikian diharapkan mereka dapat hidup memuaskan, terus berkembang dan dapat meraih cita-cita. Dengan pendidikan, manusia dapat menjalankan fungsinya sebagai hamba Allah dan khalifah-Nya. ${ }^{3}$ Begitu juga dengan pendidikan akhlak, banyak orang yang sangat rajin mempelajari ilmu namun melupakan akhlak. Banyak orang pintar dengan gelar pendidikan yang tinggi, namun akhlaknya kepada orang tua atau orang lain sangat buruk. Inilah pentingnya mempelajari ilmu akhlak sebelum ilmu lainnya.

Diantara akhlak terpuji yang harus dimiliki oleh seorang muslim adalah kesopanan, sabar, jujur, rendah hati, tutur kata lembut dan santun, gigih, rela berkorban, adil, tawakal, menepati janji, menjauhi semua yang diharamkan oleh Allah Swt., berbuat baik kepada tetangga, membantu orang yang membutuhkan sesuai kemampuan, dan lain sebagainya. Sesuai dengan konsep akhlak yang tertera dalam al-Qur'an dan sunnah yang menjelaskan tentang disyariatkanya akhlak-akhlak tersebut agar seorang muslim memiliki adab yang baik dalam menjalani kehidupanya sehari-hari. ${ }^{4}$

Termasuk di dalamnya adab anak kepada orang tua dan guru, setiap murid wajib menaati keduanya. ${ }^{5}$ Orang tua adalah orang yang pertama kali menjaga dan menyayangi

\footnotetext{
${ }^{1}$ Mirzon Daheri and Idi Warsah, "Pendidikan Akhlak: Relasi Antara Sekolah dengan Keluarga," At-Turats 13, no. 1 (May 1, 2019): 3, https://doi.org/10.24260/at-turats.v13i1.1285.

${ }^{2}$ Syaiful Anwar, "Peran Pendidikan Agama Islam Dalam Membentuk Karakter Bangsa," AlTadzkiyyah: Jurnal Pendidikan Islam 7, no. 2 (2016): 157-70, https://doi.org/10.24042/atjpi.v7i2.1500.

${ }^{3}$ M. Quraish Shihab, “Membumikan” Al-Quran: Fungsi dan Peran Wahyu dalam Kehidupan Masyarakat (Mizan Pustaka, 2007).

${ }^{4}$ M. Muhammad, “AL-Qur'an Mengantarkan Keluarga Islami Menuju Kesuksesan Dunia Akhirat," Al-I'jaz: Jurnal Kewahyuan Islam 0, no. IV (July 1, 2018), https://doi.org/10.30821/ali'jaz.v0iIV.5420; Agung Kurniawan, "Aktualisasi Nilai Khalifah dalam Al-Quran,” Jurnal Al-Dirayah 1, no. 1 (2018).

${ }^{5}$ Katni Katni and Sigit Dwi Laksana, "Model Manajemen Pendidikan Adab Anak Usia Pendidikan Dasar DI MIN Demangan Madiun Jawa Timur Indonesia," AL-MURABBI: Jurnal Studi Kependidikan dan Keislaman 6, no. 2 (February 5, 2020): 117-29; Sri Hartini, "Pendidikan Karakter
} 
anak di dunia ini. Tidak ada perjuangan yang ikhlas tanpa pamrih kecuali perjuangan kedua orang tua. ${ }^{6}$ Orang tua juga merupakan pahlawan bagi anak-anaknya bagaimanapun keadaanya. Oleh karena itu seorang anak harus berbakti dan taat kepada orang tua selagi tidak menyeleweng dari ajaran agama Islam. Ketaatan kepada orang tua merupakan bentuk "birrulwalidain" yang artinya berbakti kepada orang tua. Berbakti kepada orang tua termasuk salah satu amalan paling mulia dalam agama Islam ${ }^{7}$.

Hal ini pernah dijelaskan Rasulullah saw. dalam hadis yang diriwayatkan oleh Bukhari dan Muslim dari Mas'ud r.a.;

Dari Abdullah Ibnu Mas’ud ra berkata, ‘Aku bertanya kepada Nabi Muhammad Saw tentang amalan yang paling disukai Allah Swt? beliau menjawab, Shalat pada waktunya. Kemudian apa? Kataku, beliau menjawab, "berbuat baik kepada kedua orangtua". Kemudian apa? Kataku lagi. Beliau menjawab, "jihad fi sabilillah". (HR. Bukhari dan Muslim)

Makna hadis di atas menggambarkan bahwa akhlak kepada orang tua harus lebih didahulukan daripada jihad dijalan Allah, karena ia menempati urutan kedua dan jihad berada diurutan ketiga. Bagaimana dengan guru? Guru adalah orang dewasa yang memberikan ilmu pengetahuan kepada setiap orang meskipun satu ayat saja. ${ }^{8}$ Merekalah yang memberikan pengetahuan, baik melalui lembaga formal seperti sekolah, maupun lembaga nonformal seperti tempat kursus, majlis ta'lim, pondok pesantren dan lain sebagainya. Namun pada realitanya, di Indonesia masih banyak anak yang kurang

Disiplin Siswa di Era Modern Sinergi Orang Tua dan Guru di MTs Negeri Kabupaten Klaten," $A L$ ASASIYYA: Journal Of Basic Education 2, no. 1 (December 1, 2017), https://doi.org/10.24269/ajbe.v2i1.882.

${ }^{6}$ Idi Warsah, "Pendidikan Keluarga Muslim di Tengah Masyarakat Multi-Agama: Antara Sikap Keagamaandan Toleransi (Studi di Desa Suro Bali Kepahiang-Bengkulu)," Edukasia: Jurnal Penelitian Pendidikan Islam 13, no. 1 (2018): 1-24; Idi Warsah et al., "Muslim Minority in Yogyakarta: Between Social Relationship and Religious Motivation," QIJIS (Qudus International Journal of Islamic Studies) 7, no. 2 (December 30, 2019): 367-98, https://doi.org/10.21043/qijis.v7i2.6873.

${ }^{7}$ Nufus, Fika Pijaki, et al. "Konsep Pendidikan Birrul Walidain dalam QS. Luqman (31): 14 DAN QS. AL 'ISRA (17): 23-24." JURNAL ILMIAH DIDAKTIKA: Media Ilmiah Pendidikan dan Pengajaran 18.1 (2017): 16-31.

${ }^{8}$ Siti Suprihatin, "Upaya Guru Dalam Meningkatkan Motivasi Belajar Siswa," PROMOSI: Jurnal Program Studi Pendidikan Ekonomi 3, no. 1 (2015), https://doi.org/10.24127/ja.v3i1.144; Ade Seunjana, "Upaya Guru Al-Quran Hadist Dalam Meningkatkan Motivasi Belajar Siswa Di MTsN Jeureula Aceh Besar" (PhD Thesis, UIN Ar-Raniry Banda Aceh, 2017). 
| LENI ELPITA SARI, DKK. | Adab kepada Guru dan Orang Tua...

memahami akan pentingnya adab kepada orang tua dan guru, bahkan tidak jarang guru dipidanakan oleh orang tua siswa dengan tuduhan kekerasan terhadap anak sebagaimana hasil penelitian dari Nur Aini. ${ }^{9}$ Beberapa kasus lain misalnya, siswa tega menghilangkan nyawa gurunya karena hal sepele. ${ }^{10}$ Ada juga yang menganiaya guru hanya karena tidak terima ditegur. ${ }^{11}$ Padahal sejatinya, guru hanya mencoba mendidik muridnya agar menjadi manusia yang lebih baik.

Salah satu lembaga pendidikan yang gigih mengembangkan pendidikan akhlak untuk siswa-siswinya adalah MTSN 02 Kepahiang. MTS ini merupakan salah satu madrasah tsanawiyah yang mengedepankan dan menanamkan akhlak mulia kepada siswa-siswinya. Nilai-nilai adab lebih ditanamkan kepada siswa melalui kegiatankegiatan keagamaan. Salah satunya kegiatan pembiasaan shalat Dhuha yang telah diterapkan dan memberikan dampak positif. Dibuktikan dengan lancarnya hafalan suratsurat pendek para siswa dan indikasi lainnya yaitu ketertiban siswa-siswi ketika menjelang waktu Dhuha. Mereka biasanya menggunakan waktu pagi untuk bermainmain, namun sekarang diawali dengan melaksanakan shalat Dhuha. Sehingga mereka membiasakan diri untuk beribadah secara konsisten.

Selain itu masih banyak kegiatan lain seperti sholat Zuhur berjamaah, infaq, muhadaroh, membaca surat pendek sebelum belajar dan lain sebagainya. Dalam bidang akademik, siswa siswi di MTSN 02 Kepahiang juga telah banyak meraih prestasi seperti meraih juara II Volleyball, juara I dan III MTQ pada ajang Gebyar MAN 02 Kepahiang, Diajang lomba taekwondo tingkat provinsi yang dilaksanakan di Kabupaten Lebong. Selanjutnya meraih prestasi dengan rincian I medali emas, 2 perak, dan 3 perunggu. Diajang AKSIOMA meraih juara 1 MTQ, juara 3 Kaligrafi, juara 1 Bulutangkis putri,

\footnotetext{
${ }^{9}$ Asy'ari, Nur Aini Shofiya. "Film 'The Candle'Sebagai Literasi Media Kasus Maraknya Guru Yang Dipidanakan." ETTISAL: Journal of Communication 2.1 (2017): 41-50.

${ }^{10}$ Agus Affandi, "Dampak Pemberlakuan Undang-Undang Perlindungan Anak terhadap Guru dalam Mendidik Siswa,” Jurnal Hukum Samudra Keadilan 11, no. 2 (2016): 196-208.

${ }^{11}$ Indun Ariningsih and Rizki Amalia, "Membangun Karakter Siswa Melalui Pembelajaran Matematika yang Berintegrasi Keislaman," Journal on Teacher Education 1, no. 2 (February 18, 2020): $1-8$.
} 
juara 1 Bulutangkis putra. Sementara diajang KSM meraih juara 1 Biologi, juara 2 Matematika dan juara 1 Fisika, dan lain sebagainya. ${ }^{12}$

Akan tetapi hasil observasi yang peneliti lakukan di MTSN 02 Kepahiang yang notabene adalah sekolah Islam, masih banyak siswa yang cenderung berperilaku kurang baik. Hal ini dibuktikan dari masih adanya siswa yang mem-bully temanya hingga berujung perkelahian, mengambil barang atau uang milik temanya, berkata-kata yang tidak pantas, berpenampilan yang tidak pantas selayaknya siswa seperti mewarnai rambut, membawa HP ke sekolah, membolos ke kantin pada saat jam pelajaran berlangsung, kurangnya sopan santun kepada guru, tidak mematuhi peraturan sekolah seperti sering terlambat datang ke sekolah, tidak mematuhi perintah guru seperti tidak mengerjakan PR, acuh tak acuh terhadap pelajaran, kurang memperhatikan seperti berbicara atau bercanda dengan teman ketika guru sedang mengajar, dan meremehkan saat mendapat teguran langsung oleh guru apabila siswa melanggar peraturan. ${ }^{13}$ Dalam menghadapi masalah-masalah tersebut selain memberikan sanksi bagi para siswa yang melakukan pelanggaran, sekolah juga melibatkan pembinaan guru BK atau memanggil wali/orang tua siswa yang bersangkutan, hingga mengeluarkan siswa yang sudah terlalu banyak melakukan pelanggaran. ${ }^{14}$

Masalah-masalah seperti ini perlu ditanggulangi dengan mengarahkan pembelajaran PAI untuk mendidik siswa menjadi manusia yang benar-benar mempunyai kualiatas keagamaan yang kuat dan mampu menerapkanya dalam kehidupanya sehari-hari. Sehingga proses pendidikan tidak hanya mengajarkan tentang ilmu pengetahuan agama saja. Namun selain dari usaha guru, seharusnya peserta didik dapat mempelajari tentang apa yang salah agar dapat menyelesaikan tugas perkembangan dengan baik. ${ }^{15}$ Dengan begitu peserta didik dapat mengantisipasi perubahan dengan cepat dan tepat. Oleh karena itu peserta didik dibekali dengan

\footnotetext{
${ }^{12}$ Hasil observasi tanggal 4 Februari 2020.

${ }^{13}$ Hasil observasi dari 15 Januari hingga 15 Februari 2020.

${ }^{14}$ Hasil wawancara dengan Bpk Zuhirin selaku WAKA kurikulum MTSn 02 Kepahiang.

${ }^{15}$ Idi Warsah, "Pendidikan Keimanan sebagai Basis Kecerdasan Sosial Peserta Didik:Telaah Psikologi Islami,” Psikis: Jurnal Psikologi Islami 4, no. 1 (2018): 1-16.
} 
| LENI ELPITA SARI, DKK. | Adab kepada Guru dan Orang Tua...

pemahaman tentang pendidikan Islam yang baik agar tidak melakukan tindakantindakan yang merugikan dirinya sendiri dan lingkunganya.

Salah satu mata pelajaran yang mengajarkan dan mendidik tentang adab peserta didik adalah Akidah Akhlak. Mata pelajaran Akidah Akhlak merupakan sub bab mata pelajaran Pendidikan Islam (PAI) yang diajarkan pada jenjang pendidikan madrasah yang didalamnya membahas tentang ajaran agama Islam dari segi Aqidah dan Akhlak. Pendidikan agama Islam di sekolah maupun di madrasah memiliki aspek-aspek yang sama yaitu aspek hubungan manusia dengan Allah Swt, aspek hubungan manusia dengan sesamanya, dan aspek hubungan manusia dengan alam. ${ }^{16}$ Pendidikan Agama Islam di madrasah terdiri dari empat mata pelajaran, yaitu: al-Qur'an dan Hadis, Aqidah Akhlak, Fiqih dan Sejarah Kebudayaan Islam. Empat macam cakupan tersebut setidaknya menggambarkan bahwa ruang lingkup pendidikan agama Islam diharapkan dapat mewujudkan keselarasan, keserasian, dan keseimbangan hubungan manusia dengan Allah, diri sendiri, sesama manusia, makhluk lainnya maupun lingkungannya. ${ }^{17}$

Dengan mempelajari akhlak ini, maka harapannya dapat menjadi sarana bagi siswa untuk menjadi manusia yang sempurna atau insan kamil. Akan tetapi, akankah pemahaman siswa pada mata pelajaran Akidah Akhlak berpengaruh pada adab siswa dalam kehidupanya sehari-hari. Oleh karena itu, dengan latar belakang yang telah dipaparkan di atas, penelitian ini bertujuan untuk menggali lebih mendalam dan diuraikan secara deskrptif tentang pengetahuan siswa MTs.N 2 Kepahiang terhadap adab dan sopan santun baik kepada orang tua maupun guru yang diajarkan melalui materi akhlak dan gambaran realisasinya dalam kehidupan sehari-hari mereka.

Penelitian menggunakan pendekatan kualitatif, yaitu prosedur penelitian yang menghasilkan data deskriptif berupa kata-kata tertulis atau lisan dari orang-orang dan perilaku yang diamati. Pendekatan diarahkan pada latar dan individu tersebut secara holistik atau utuh. Jadi dalam hal ini individu atau organisasi tidak disosialisasikan

\footnotetext{
${ }^{16}$ Ahmad Munjin Nasih \& Lilik Nur Kholidah, Metode dan Teknik Pembelajaran Pendidikan Agama Islam, (Bandung: PT Refika Aditama, 2009), 10.

${ }^{17}$ Nasih \& Kholidah, Metode dan Teknik Pembelajaran ..., 47.
} 
kedalam variable atau hipotesis tetapi dipandang sebagai bagian dari suatu keutuhan. ${ }^{18}$ Pendapat ini juga didukung dengan pendapat yang dikemukakan oleh Winarno yakni "Penyelidikan metode deskriptif tertuju pada pemecahan masalah yang ada pada masa sekarang". 19

Penelitian ini memilih pendekatan deskriptif kualitatif dikarenakan permasalahan penelitian bersifat holistic, kompleks, dinamis dan penuh makna. Serta penulis bermaksud memahami situasi sosial secara mendalam, menemukan pola, hipotesis dan teori. Oleh karena itu untuk memperoleh jawaban permasalahan di atas, digunakan teknik wawancara dan observasi. Selanjutnya data dianalisis dengan pendekatan yang berbasis pada model interaktif versi Miles et al. yang meliputi pengumpulan data, pemadatan data, penyajian data, dan penyimpulan data.

\section{B. Pembahasan}

\section{Urgensi Pemahaman Siswa dalam Proses Belajar.}

Konsep pemahaman, ia adalah hasil dari proses belajar, misalnya anak didik dapat menjelaskan dengan susunan kalimat sendiri atas apa yang dibacanya atau didengarnya, memberi contoh lain dari yang telah dicontohkan guru atau menggunakan petunjuk penerapan pada kasus lain. ${ }^{20}$ Pemahaman dapat dibedakan menjadi 3 kategori, yaitu: a) Tingkat terendah, yakni pemahaman terjemahan mulai dari terjemahan dalam arti yang sebenarnya. Misalnya dari bahasa Arab ke bahasa Indonesia; b) Tingkat sedang, yakni pemahaman penafsiran yaitu menghubungkan bagian-bagian terdahulu yang diketahui berikutnya atau menghubungkan beberapa bagian dari grafik kejadian; c) Tingkat tinggi, yakni pemahaman ekstrapolasi. ${ }^{21}$ Dengan ekstrapolasi diharapkan seseorang mampu melihat dibalik yang ditulis dan dapat membuat ramalan konsekuensi atau dapat memperluas persepsi dalam arti waktu, dimensi, kasus atau masalahnya.

\footnotetext{
${ }^{18}$ Lexy. J. Moleong, Metode Penelitian Kualitatif (Bandung: Remaja Rosdakarya, 2003), 3.

${ }^{19}$ Winarno Surakmad, Pengantar Penelitian Metode Dan Riset (Bandung: Tarsito. 1990), 139.

${ }^{20}$ Nana Sudjana, Penilaian Hasil Proses Belajar Mengajar (Bandung: Remaja Rosdakarya, 1995), 24

${ }^{21}$ Awaluddin Makaraka and Sarwah Sarwah, "Peran Pedagogical Content Knowledge (PCK) Guru untuk Meningkatkan Pemahaman Siswa dalam Pembelajaran," Prosiding 4, no. 1 (December 1, 2018), http://journal.uncp.ac.id/index.php/proceding/article/view/1319.
} 
| LENI ELPITA SARI, DKK. | Adab kepada Guru dan Orang Tua...

Pengertian pemahaman di atas, diperoleh gambaran bahwa siswa dapat memahami apabila siswa mengerti serta mampu untuk menjelaskan kembali dengan kata-katanya sendiri tentang materi pelajaran yang telah disampaikan oleh guru serta mampu menerapkan kedalam konsep-konsep lain serta mampu menerapkan dalam kehidupan sehari-hari.

\section{Adab kepada Orang Tua dan Guru}

a. Pengertian Adab

Adab menurut bahasa adalah kesopanan, kehalusan, akhlak atau bisa juga sopan santun dan dalam kosa-kata bahasa Arab, kata Adab berasal dari tashrifan (adaba$y a^{\prime} d u b u$ ) yang berarti mengundang atau mengajak. ${ }^{22}$ Dinamakan adab karena ia mengajak manusia kepada perbuatan terpuji dan mencegah manusia dari perbuatan keji dan munkar. Sedangkan menurut istilah, Adab berarti norma atau perilaku sopan santun kepada orang lain terutama kepada orang yang lebih tua agar pergaulan sesama manusia tetap terjaga dan harmonis yang didasarkan atas aturan agama, terutama agama Islam.

Orang tua adalah orang yang melahirkan, merawat, membesarkan, dan mendidik kita sejak masih didalam kandungan hingga dewasa. ${ }^{23}$ Sedangkan guru adalah orangtua kedua yang telah berjasa dalam mendidik pada jalur lembaga pendidikan baik formal maupun nonformal. ${ }^{24}$ Jadi adab kepada orang tua dan guru adalah berperilaku sopan dan santun kepada orang tua atau guru sesuai dengan aturan agama dan dalam lingkungan masyarakat tidak melanggar norma-norma yang ada.

b. Dalil perintah beradab kepada orang tua dan guru

Islam merupakan agama yang sempurna, sehingga setiap ajaran yang ada dalam Islam memiliki dasar pemikiran. Begitu pula dengan pendidikan akhlak anak terhadap

\footnotetext{
${ }^{22}$ Umam B. Karyanto, "MAKNA DASAR PENDIDIKAN ISLAM (Kajian Semantik) | Forum Tarbiyah" 9, no. 2 (2012): 155-58.

${ }^{23}$ Wirawan, Yahya Reka. "Pengaruh Status Sosial Ekonomi Orang Tua Terhadap Prestasi Belajar Ekonomi Dan Perilaku Konsumsi Siswa." Jurnal Ekonomi Pendidikan dan Kewirausahaan 3.2 (2017): 147-167.

${ }^{24}$ Idi Warsah and Muhamad Uyun, "Kepribadian Pendidik: Telaah Psikologi Islami," Psikis: Jurnal Psikologi Islami 5, no. 1 (2019): 62-73.
} 
kedua orang tua dan gurunya. Bukti utama bahwa berbakti kepada orang tua merupakan salah satu ajaran Islam yang paling tinggi setelah iman kepada Allah Swt. adalah firman Allah Swt. yang tertuang dalam al-Qur'an maupun Hadis Rasulullah yang dijadikan sebagai sumber utama ajaran Islam, saking kukuhnya kewajiban itu Allah mengulangulang perintah berbakti kepada orang tua setelah perintah beribadah beribadah kepadaNya dalam beberapa ayat al-Qur'an dan Hadis diantaranya:

1) Q.S. Al-Isra Ayat 23-24

"Dan Tuhanmu telah memerintahkan agar kamu jangan menyembah selain Dia dan hendaklah berbuat baik kepada ibu bapak. Jika salah seorang diantara kedua-duanya sampai berusia lanjut dalam pemeliharaanmu, maka sekali-kali janganlah engkau mengatakan kepadanya perkataan "ah" dan janganlah engkau membentak keduanya, dan ucapkanlah kepada keduanya perkataan yang baik. Dan rendahkanlah dirimu terhadap keduanya dengan penuh kasih sayang dan ucapakanlah,"Wahai Tuhanku! Sayangilah keduaanya sebagaimana mereka berdua telah mendidik aku pada waktu kecil".

Dalam ayat tersebut Allah memerintahkan kepada hamba-hamba-Nya untuk menyembah Allah Swt semata, tidak ada sekutu bagi-Nya. Kandungan ayat ini juga menunjukkan betapa kaum muslimin memiliki kedudukan yang sangat tinggi dibanding dengan kaum yang mempersekutukan Allah Swt. Ayat ini juga menjelaskan tentang ihsan (bakti) kepada orang tua yang diperintahkan agama Islam adalah bersikap sopan kepada keduanya. Ayat tersebut juga menerangkan larangan kepada manusia membentak orang tua, bahkan berkata "ah" saja tidak diperbolehkan. Sehingga Allah menganjurkan untuk manusia berkata dan berbuat yang baik dan mulia terhadap keduanya sesuai dengan adat kebiasaan masyarakat, sehingga mereka merasa senang, serta mencukupi kebutuhan-kebutuhan mereka yang sah dan wajar sesuai kemampuan setiap individu sebagai anak ${ }^{25}$.

${ }^{25}$ Nufus, Fika Pijaki, et al. "Konsep Pendidikan Birrul Walidain Dalam QS. Luqman (31): 14 DAN QS. AL ISRA (17): 23-24." Jurnal Ilmiah Didaktika: Media Ilmiah Pendidikan dan Pengajaran 18.1 (2017): 16-31. 
| LENI ELPITA SARI, DKK. | Adab kepada Guru dan Orang Tua...

2) Q.S. An-Nahl Ayat 43

... Maka bertanyalah kepada orang yang memiliki pengetahuan jika kamu tidak mengetahui". Ayat tersebut menjelaskan tentang guru, bahwa guru adalah orang yang memberi ilmu, dia adalah orang yang mempunyai ilmu/pengetahuan sesuai dengan bidang masing-masing. ${ }^{26}$ Guru tempat bertanya bagi orang yang membutuhkan pengetahuan (tidak mengetahui) tentang suatu ilmu tertentu. Oleh karena itu, guru wajib dihormati dan dihargai.

3) Q.S. Al-Baqarah ayat 83

Dan (ingatlah) ketika kami mengambil janji dari Bani Israil, "janganlah kamu menyembah selain Allah, berbuat baiklah kepada kedua orang tua, kerabat, anak-anak yatim dan orang miskin". Ayat tersebut menerangkan bahwa perintah beribadah hanya kepada Allah Swt. yang disusul dengan perintah berbakti kepada orang tua. Memang, mengabdi kepada Allah harus di tempatkan pada tempat yang pertama, karena Dia adalah sumber wujud manusia dan sumber sarana kehidupannya. Setelah itu, baru kepada orang tua yang menjadi perantara bagi kehidupan seseorang serta memeliharanya hingga dapat berdiri sendiri. ${ }^{27}$

Berdasarkan ayat dan tafsir di atas jelaslah bahwa keharusan berbuat baik kepada orang tua yang didahului dengan menyembah hanya kepada Allah Swt. Berbuat baik tidak hanya kepada orang tua, namun termasuk kepada kerabat, anak yatim dan orang miskin.

4) Q.S. Luqman ayat 14-15

"Dan kami perintahkan kepada manusia (berbuat baik) kepada dua orang ibu-bapaknya, ibunya telah mengandungnya dalam keadaan lemah yang bertambah- tambah dan menyapihnya dalam dua tahun. Bersyukurlah kepada$\mathrm{Ku}$ dan kepada dua orang ibu bapakmu, hanya kepadaKu-lah kembalimu”(14). "Dan jika keduanya memaksamu untuk mempersekutukan

\footnotetext{
${ }^{26}$ Rahma Diani, "Pengaruh Pendekatan Saintifik Berbantukan LKS Terhadap Hasil Belajar Fisika Peserta Didik Kelas XI SMA Perintis 1 Bandar Lampung," Jurnal Ilmiah Pendidikan Fisika Al-Biruni 5, no. 1 (April 27, 2016): 83-93, https://doi.org/10.24042/jpifalbiruni.v5i1.108.

${ }^{27}$ M. Quraish Shihab, Tafsir Al-Misbah: Pesan, Kesan, dan Keserasian Al-Qur'an (Jakarta: Lentera Hati, 2006), 247
} 
Aku dengan sesuatu yang engkau tidak mempunyai ilmu tentang itu, maka janganlah engkau menaati keduanya, dan pergaulilah keduanya di dunia dengan baik, dan ikutilah jalan orang yang kembali kepada-Ku. Kemudian hanya kepada-Ku tempat kembalimu, maka aku beritahukan kepadamu apa yang telah kamu kerjakan" (15).

Ayat di atas menyatakan (dan kami wasiatkan) yakni berpesan dengan amat kukuh kepada semua manusia menyangkut kedua orang ibu bapaknya, pesan kami disebabkan karena ibunya telah mengandungnya dalam keadaan kelemahan di atas kelemahan, yakni kelemahan berganda dan bertambah-tambah. Lalu dia melahirkannya dengan susah payah, kemudian memelihara dan menyusukannya setiap saat, bahkan ditengah malam, ketika manusia lain tertidur nyenyak. ${ }^{28}$

Ayat-ayat tersebut, mengaitkan perintah menyembah Allah dengan perintah berbakti kepada orang tua. Dari sudut pandang struktur kalima bahwa, perintah untuk menyembah Allah dan berbakti terhadap orang tua tidak dapat dipisahkan. Sehingga berbakti terhadap orang tua menjadi tolak ukur bagi kualitas penghambaan manusia kepada Allah. Ketika seorang hamba taat terhadap perintah orang tua maka dapat dikatakan anak tersebut juga melakukan perintah Allah.

Sementara itu terdapat beberapa hadis yang menjadi dasar pentingnya adab kepada orang tua dan guru, antara lain:

1) H.R. Bukhari dan Muslim

"Dari Al Walid bin 'Aizar, dia berkata aku mendengar Abu Amr AsySyaibani berkata pemilik rumah ini seraya menunjuk dengan tangannya rumah Abdullah mengabarkan kepada kami, dia berkata "aku pernah bertanya pada Nabi Saw, apa perbuatan yang dicintai Allah, maka beliau bersabda, "shalat pada waktunya." "aku bertanya, "kemudian apa?" beliau bersabda, "berbakti kepada orang tua." Aku bertanya lagi "kemudian apa?,"beliau bersabda, "berjihad dijalan Allah." Abdullah berkata, "beliau menceritakan hal-hal itu padaku. Kalau aku meminta tambahan kepada beliau, niscaya beliau akan menambahkan kepadaku.” (HR. Bukhari dan Muslim)

\footnotetext{
${ }^{28}$ Shihab, Tafsir Al-Misbah:..., 129
} 
| LENI ELPITA SARI, DKK. | Adab kepada Guru dan Orang Tua...

Hadis tersebut menjelaskan bahwa menghormati atau berbakti terhadap orang tua lebih utama dari pada jihad. Orang Islam yang memiliki akhlak yang baik pastinya akan menghormati dan berbakti kepada kedua orang tuanya. Dengan demikian segala bentuk perilaku seorang anak yang menyatakan dirinya Muslim hendaknya merealisasikan kedua sumber tersebut dalam kehidupan sehari-hari, baik dalam lingkungan masyarakat dan sekolah. Bahkan lebih khusus dalam lingkungan keluarga. Karena di dalam lingkungan keluraga terdapat kedua orang tua yang telah merawat dan menjaga anaknya.

2) H.R. Ahmad

"Ubadah bin Samit berkata, Rasulullah Saw. Bersabda: "tidak termasuk golongan kami orang yang tidak memuliakan yang lebih tua dan menyayangi yang lebih muda serta tidak mengerti (hak) orang yang berilmu (agar diutamakan pandangannya)."

Hadis tersebut bermakna bahwa yang dimaksud orang yang berilmu adalah guru, dan seorang guru wajib diperlakukan sesuai dengan haknya. Akhlak serta beradab yang baik merupakan kewajiban yang tidak boleh dilupakan bagi seorang murid terhadap gurunya. ${ }^{29}$ Memuliakan guru adalah tugas kedua bagi setiap murid setelah memuliakan kedua orang tua, sebab keberkahan ilmu yang telah diperoleh dalam proses belajar sangat tergantung pada keiklasan guru.

\section{Upaya Guru Membiasakan Siswa MTs.N 02 Kepahiang dalam Menerapkan Pemahaman Adab kepada Orang Tua dan Guru}

Berdasarkan hasil wawancara kepada guru Akidah Akhlak diperoleh gambaran bahwa, agar seorang anak dan seorang siswa dapat berperilaku baik (beradab) kepada kedua orang tuanya dan gurunya, ada beberapa cara untuk dilakukan. Tentu cara-cara ini diberikan dengana tujuan agar terbiasa bagi anak dan siswa untuk diamalkan dalam

\footnotetext{
${ }^{29}$ Julita Widya Dwintari, "Kompetensi Kepribadian Guru dalam Pembelajaran Pendidikan Kewarganegaraan Berbasis Penguatan Pendidikan Karakter," Jurnal Pendidikan Kewarganegaraan 7, no. 2 (December 15, 2017): 51-57, https://doi.org/10.20527/kewarganegaraan.v7i2.4271; Moch Tolchah, "Studi Perbandingan Pendidikan Akhlak Perspektif Al-Ghazāli Dan al-Attas," EL-BANAT: Jurnal Pemikiran Dan Pendidikan Islam 9, no. 1 (June 2, 2019): 79-106.
} 
kehidupan sehari-hari. Dikarenakan terbiasa, lama kelamaan berbuat baik akan terasa ringan, tanpa beban, dan tidak ada paksaan dari siapapun untuk berbuat baik.

Selain itu berdasarkan hasil observasi, guru di MTs. N 02 Kepahiang memberikan pembelajran beberapa cara beradab yang baik kepada orang tua yang diselipkan ke dalam materi akhlak antara lain sebagai berikut: 1) Menyadari bahwa adanya anak karena terlebih dulu adanya orang tua; 2) Menyadari bahwa di dunia ini tidak ada orang yang mengasihi lita tanpa pamrih selain kedua orang tua; 3) Berusaha menjaga komunikasi (keakraban) dengan ibu dan ayah setiap hari; 4) Membiasakan berfikir bahwa kebahagiaan anak adalah kebahagiaan orang tua, maka jika ada kebahagiaan yang diutamakan untuk orang tua; dan 5) Selalu mendoakan orang tua.

Sedang tata cara adab siswa yang baik kepada guru, antara lain adalah: 1) Menyadari bahwa kita dapat pintar dan berakhlak baik karena diajar dan dibimbing oleh guru; 2) Menyadari bahwa pekerjaan guru adalah mulia; 3) Menyapa terlebih dahulu apabila bertemu di jalan dan di tempat-tempat tertentu; 4) Membiasakan mengindahkan nasihat dan tugas-tugas dari guru; 5) Selalu mendoakan guru.

Bagi guru mata pelajaran akhlak dan guru yang lain, memang menemukan banyak kendala dalam membina murid-murid mereka dalam menerapkan adab baik kepada ornag tua maupun kepada guru di sekolah. Namun paling tidak mereka berharap dengan diberikannya materi dan pengertian akan pentingnya menjaga abab dan akhlak kepada orang tua dan guru akan memberikan manfaat bagi mereka di kemudian hari.

Manfaat dimaksud antara lain: 1) Beradab kepada kedua orang tua adalah amal yang paling utama karena Allah Swt: 2) Menjalankan perintah Allah Swt dan RasulNya: 3) Ridha Allah Swt., tergantung kepada keridhaan orang tua; 4) Dapat menghilangkan kesulitan yang sedang dialami, yaitu dengan cara ber-tawassul dengan amal shalih tersebut: 5) Dapat meluaskan rezeki dan memanjangkan umur: 6) Dapat memasukkan seorang anak ke dalam surga; 7) Dapat menghapus dosa-dosa; 8) Akan mendapatkan kedudukan yang mulia di dunia dan di akhirat; 9) Akan berdampak positif bagi diri sendiri dan orang lain; 10) Semakin dekat hubungan anak dengan orang tua; 
| LENI ELPITA SARI, DKK. | Adab kepada Guru dan Orang Tua...

11) Doa-doanya akan lebih dikabulkan; 12) Anak yang mengasihi orang tua biasanya hidupnya sejahtera.

Adapun manfaat berbuat baik (beradab) kepada guru, antara lain sebagi berikut: 1) Menjalankan perintah Allah Swt, dan Rasul-nya; 2) Ilmu yang didapat akan lebih bermanfaat; 3) Lebih tenang dalam mengamalkan ilmu; 4) Memperkuat ukhuwah islamiah; 5) Melatih diri dari jasa-jasa orang lain.

Sejalan dengan hal itu, berdasarkan hasil observasi di lapangan diperoleh gambaran bahwa, para guru khususnya guru Akidah Akhlak menekankan kepada setiap siswa untuk membiasakan secara praktik adab kepada orang tua dan guru. Praktik beradab kepada orang tua maksudnya adalah perilaku-perilaku baik yang semestinya dilakukan oleh seorang anak kepada orang tua sejak kecil hingga dewasa dan sampai orang tua kembali ke haribaan Allah Swt. (meninggal dunia). Seorang anak dikatakan shalih/shalihah tentunya dia selalu berbuat baik kepada kedua orang tuanya dan gurunya. Adapun adab kepada orang tua yang ditanamkan oleh guru dan dievaluasi dengan memantau siswa di rumah, terutama hal-hal sebagai berikut:

1) Bagaimana wujud kecintaan dan kasih sayang para siswa terhadap orang tua;

2) Manaati perintah keduanya;

3) Menjaga perasaan keduanya;

4) Tidak memanggil kedua orang tua dengan namanya;

5) Merendahkan diri (hati) dan tidak mendahuluinya ketika berjalan;

6) Mendoakan keduanya baik mereka masih hidup atau sudah wafat;

7) Berbuat baik kepada teman-teman orang tua (termasuk ketika orang tua sudah wafat);

8) Tidak mencaci maki kedua orang tua (termasuk mencaci maki orang tua orang lain kemudian orang tersebut membalas mencaci kedua orang tua kita);

9) Tidak mengeraskan suara melebihi suara kedua orang tua;

10) Menjawab panggilan orang tua dengan jawaban yang sopan;

11) Bersedia melayani dengan lemah lembut dan kesabaran, terutam bagi orang tua yang sangat membutuhkan pelayanannya; 
12) Tidak mengungkit-ungkit kebaikan yang telah diberikan kepada orang tua;

13) Tidak memandang wajah orang tua dengan wajah cemberut.

Indikator yang dibuat oleh guru ini tentu dikomunikasikan kepada setiap wali siswa, dan dapat menjadi tolok ukur keberhasilan belajar siswa di sekolah. Sehingga diketahui apakah pemahaman yang diperoleh oleh siswa di sekolah betul-betul dapat diterapkan oleh mereka di rumah masing-masing. Begitu juga realisasi adab dengan guru, guru Akidah membuat indicator seperti:

1) Menghormati dan menghargai guru;

2) Tidak mencari-cari kesalahan-kesalahan dan kelemahan-kelemahan guru;

3) Tidak membicarakan yang buruk tentang gurunya;

4) Mendoakan guru;

5) Mengambil sesuatu hal yang baik dari guru;

6) Mengamalkan ilmu yang telah diberikan oleh guru;

7) Menjaga adab berbicara kepada guru;

8) Taat perintah guru;

9) Meminta izin kepada guru;

10) Memberikan perhatian kepada guru;

11) Menjaga hubungan baik dengan guru.

Tentu hal ini tidak hanya diterapkan oleh siswa saat proses belajar berlangsung, atau di sekolah saja. Saat mereka di luar sekolah pun tetap harus menjaga adab dan akhlak yang baik kepada setiap guru yang berada di lingkungan MTs N 02 Kepahiang.

\section{Kesimpulan}

Simpulan yang peroleh dari penelitian ini adalah sebagai berikut: pemahaman sebagian besar peserta didik di MTs Negeri 02 Kepahiang tentang pentingnya adab kepada guru maupun orang tua sudah menunjukan kemajuan positif, meskipun masih banyak yang belum menerapkan apa yang mereka dapatkan dari guru dan berbagai kegiatan-kegiatan keagamaan baik di dalam maupun di luar kelas pada saat pembelajaran berlangsung. Namun guru mata pelajaran Akidah Akhlak sudah berusaha 
| LENI ELPITA SARI, DKK. | Adab kepada Guru dan Orang Tua...

dan cukup membantu dalam memberikan pemahaman kepada siswa dalam hal adab kepada orang tua dan guru, hal ini terlihat dari perilaku peserta didik dalam menjalani aktivitas di sekolah maupun di luar sekolah. 


\section{Daftar Pustaka}

Affandi, Agus. "Dampak Pemberlakuan Undang-Undang Perlindungan Anak terhadap Guru dalam Mendidik Siswa.” Jurnal Hukum Samudra Keadilan 11, no. 2 (2016): 196-208.

Asy'ari, Nur Aini Shofiya. "Film 'The Candle'Sebagai Literasi Media Kasus Maraknya Guru Yang Dipidanakan." ETTISAL: Journal of Communication 2.1 (2017): 41

Anwar, Syaiful. "Peran Pendidikan Agama Islam Dalam Membentuk Karakter Bangsa." AlTadzkiyyah: Jurnal Pendidikan Islam 7, no. 2 (2016): 157-70. https://doi.org/10.24042/atjpi.v7i2.1500.

Ariningsih, Indun, and Rizki Amalia. "Membangun Karakter Siswa Melalui Pembelajaran Matematika yang Berintegrasi Keislaman." Journal on Teacher Education 1, no. 2 (February 18, 2020): $1-8$.

Daheri, Mirzon, and Idi Warsah. "Pendidikan Akhlak: Relasi Antara Sekolah Dengan Keluarga.” At-Turats 13, no. 1 (May 1, 2019): 3. https://doi.org/10.24260/at-turats.v13i1.1285.

Diani, Rahma. "Pengaruh Pendekatan Saintifik Berbantukan LKS Terhadap Hasil Belajar Fisika Peserta Didik Kelas XI SMA Perintis 1 Bandar Lampung." Jurnal Ilmiah Pendidikan Fisika AlBiruni 5, no. 1 (April 27, 2016): 83-93. https://doi.org/10.24042/jpifalbiruni.v5i1.108.

Dwintari, Julita Widya. "Kompetensi Kepribadian Guru dalam Pembelajaran Pendidikan Kewarganegaraan Berbasis Penguatan Pendidikan Karakter." Jurnal Pendidikan Kewarganegaraan 7, no. 2 (December 15, 2017): 51-57. https://doi.org/10.20527/kewarganegaraan.v7i2.4271.

Hartini, Sri. "Pendidikan Karakter Disiplin Siswa di Era Modern Sinergi Orang Tua dan Guru di MTs Negeri Kabupaten Klaten." AL-ASASIYYA: Journal Of Basic Education 2, no. 1 (December 1, 2017). https://doi.org/10.24269/ajbe.v2i1.882.

Katni, Katni, and Sigit Dwi Laksana. "Model Manajemen Pendidikan Adab Anak Usia Pendidikan Dasar di MIN Demangan Madiun Jawa Timur Indonesia." AL-MURABBI: Jurnal Studi Kependidikan dan Keislaman 6, no. 2 (February 5, 2020): 117-29.

Kurniawan, Agung. “Aktualisasi Nilai Khalifah dalam Al-Quran.” Jurnal Al-Dirayah 1, no. 1 (2018).

Makaraka, Awaluddin, and Sarwah Sarwah. "Peran Pedagogical Content Knowledge (PCK) Guru untuk Meningkatkan Pemahaman Siswa Dalam Pembelajaran." Prosiding 4, no. 1 (December 1, 2018). http://journal.uncp.ac.id/index.php/proceding/article/view/1319.

Moleong, Lexy. J. Metode Penelitian Kualitatif. Bandung: Remaja Rosdakarya, 2003

Muhammad, M. "Al-Qur'an Mengantarkan Keluarga Islami Menuju Kesuksesan Dunia Akhirat.” Al-I'jaz: Jurnal Kewahyuan Islam 0, no. IV (July 1, 2018). https://doi.org/10.30821/al-i'jaz.v0iIV.5420. 
| LENI ELPITA SARI, DKK. | Adab kepada Guru dan Orang Tua...

Nasih, A. Munjin \& Lilik Nur Kholidah, Metode dan Teknik Pembelajaran Pendidikan Agama Islam. Bandung: Refika Aditama, 2009.

Nufus, Fika Pijaki, et al. "Konsep Pendidikan Birrul Walidain dalam QS. Luqman (31): 14 DAN QS. AL 'ISRA (17): 23-24." Jurnal Ilmiah Didaktika: Media Ilmiah Pendidikan dan Pengajaran 18.1 (2017): 16-31

Seunjana, Ade. "Upaya Guru Al-Quran Hadist Dalam Meningkatkan Motivasi Belajar Siswa Di MTsN Jeureula Aceh Besar.” PhD Thesis, UIN Ar-Raniry Banda Aceh, 2017.

Shihab, M. Quraish. "Membumikan” Al-Quran: Fungsi dan Peran Wahyu dalam Kehidupan Masyarakat. Mizan Pustaka, 2007.

Tafsir Al-Misbah: Pesan, Kesan, dan Keserasian Al-Qur'an. Jakarta: Lentera Hati, 2006.

Sudjana, Nana. Penilaian Hasil Proses Belajar Mengajar. Bandung: Remaja Rosdakarya, 1995.

Surakmad, Winarno. Pengantar Penelitian Metode Dan Riset. Bandung: Tarsito. 1990

Suprihatin, Siti. "Upaya Guru dalam Meningkatkan Motivasi Belajar Siswa." PROMOSI:

Jurnal Program Studi Pendidikan Ekonomi 3, no. 1 (2015). https://doi.org/10.24127/ja.v3i1.144.

Tolchah, Moch. "Studi Perbandingan Pendidikan Akhlak Perspektif Al-Ghazāli Dan al-Attas." EL-BANAT: Jurnal Pemikiran Dan Pendidikan Islam 9, no. 1 (June 2, 2019): 79-106.

Umam B. Karyanto. "Makna Dasar Pendidikan Islam (Kajian Semantik) | Forum Tarbiyah" 9, no. 2 (2012): 155-58.

Warsah, Idi. "Pendidikan Keimanan Sebagai Basis Kecerdasan Sosial Peserta Didik: Telaah Psikologi Islami." Psikis: Jurnal Psikologi Islami 4, no. 1 (2018): 1-16.

"Pendidikan Keluarga Muslim di Tengah Masyarakat Multi-Agama: Antara Sikap Keagamaandan Toleransi (Studi di Desa Suro Bali Kepahiang-Bengkulu)." Edukasia: Jurnal Penelitian Pendidikan Islam 13, no. 1 (2018): 1-24.

Warsah, Idi, Yusron Masduki, Imron Imron, Mirzon Daheri, and Ruly Morganna. "Muslim Minority in Yogyakarta: Between Social Relationship and Religious Motivation." QIJIS (Qudus International Journal of Islamic Studies) 7, no. 2 (December 30, 2019): 367-98. https://doi.org/10.21043/qijis.v7i2.6873.

Warsah, Idi, and Muhamad Uyun. "Kepribadian Pendidik: Telaah Psikologi Islami." Psikis: Jurnal Psikologi Islami 5, no. 1 (2019): 62-73.

Wirawan, Y. Reka. "Pengaruh Status Sosial Ekonomi Orang Tua Terhadap Prestasi Belajar Ekonomi Dan Perilaku Konsumsi Siswa." Jurnal Ekonomi Pendidikan dan Kewirausahaan 3.2 (2017): 147-167. 